\title{
Description of Seedless Grape Drying and Determination of Drying Rate
}

\author{
Wilton Pereira da Silva (Corresponding author) \\ Federal University of Campina Grande, Paraiba, Brazil \\ Tel: 55-833-333-2962Ｅ-mail: wiltonps@uol.com.br
}

Pedro Luiz do Nascimento

Federal University of Campina Grande, Paraiba, Brazil

E-mail: pedropln@yahoo.com.br

Cleide Maria Diniz Pereira da Silva e Silva

Federal University of Campina Grande, Paraiba, Brazil

E-mail: cleidedps@uol.com.br

Josivanda Palmeira Gomes

Federal University of Campina Grande, Paraiba, Brazil

josivanda@gmail.com

Ihsan Hamawand

National Centre for Engineering in Agriculture, University of Southern, Australia

E-mail: Ihsan.hamawand@usq.edu.au

Received: February 27, 2014 Accepted: March 19, 2014

doi:10.5296/jas.v2i2.5192 URL: http://dx.doi.org/10.5296/jas.v2i2.5192 


\section{Abstract}

This article compares some empirical models, with one or two parameters, used to describe seedless grape drying at low temperature. Chosen models have, as a common characteristic, an analytical expression for the derivative of dimensionless moisture content with respect to time. Comparison of the results for the simulations of drying kinetics indicates that, despite Page and Silva et alli models well represent the process, the best model is Peleg. For this model, the statistical indicators of the simulation can be considered excellent (the determination coefficient is $\mathrm{R}^{2}=0.99944$ and the chi-square is $\chi^{2}=1.2335 \times 10^{-3}$ ).

Keywords: Drying rate, Process time, Mathematical model, Raisins, Drying kinetics.

\section{Introduction}

Grapes are fruits among the most perishable foods, compared with other agricultural products. They are very susceptible to microbial decay and moisture loss. To prolong the consuming time of grapes, the drying mechanism is usually applied. This process results in a food very appreciated in several parts of the world: raisins. To increase the drying rate, a pretreatment is usually accomplished. According to Silva et al. (2012a), several pretreatment techniques involving the use of chemical additives are described in the literature (Pangavhane et al., 1999; Doymaz and Pala, 2002; Doymaz, 2006; Esmaiili et al., 2007). However, several authors observe that the demand for natural foods is increasing in many parts of the world. Thus, alternatives to chemical additives are used as pretreatment for the production of raisins, such as abrasion (Di Matteo et al., 2000) and dipping in hot water (Esmaiili et al., 2007; Ramos et al., 2010). For example, Esmaiili et al. (2007) studied drying of seedless grapes submitted to two types of pretreatments, as is described in the following. The grapes were dipped in an alkaline emulsion of ethyl oleate (EO) and also in hot water (HW) before drying. According to the authors, the EO solution was prepared at room temperature by adding $2 \%$ ethyl oleate to a $5 \%$ solution of potassium carbonate. For HW, tap water was heated to approximately $95{ }^{\circ} \mathrm{C}$. Dipping times in EO and HW were 60 and 15 s, respectively.

To describe thin-layer drying of an agricultural product, two main groups of models are frequently found in the literature. The first group corresponds to the diffusion models (Karim and Hawlader, 2005; Da Silva et al., 2012a, 2012b and 2012c; Mabellini et al., 2013) and second one corresponds to the empirical models (Turhan et al., 2002; Diamante et al., 2010; Kaleta and Gornicki, 2010; Sahoo et al., 2012; Silva et al., 2012b; Malekjani et al., 2013). Empirical models are important not only to describe thin-layer water removal, but also to describe the heat penetration during this removal when hot air is used. In this case, heating is governed by the diffusion equation, that involves the drying rate in the energy balance (Karim and Hawlader, 2005; Mariani et al., 2008), and this rate can be determined by an empirical model. Generally, an empirical model is also used in the study of deep bed drying. According to Silva et al. (2013), in some methods of simulation, the deep bed is divided into several thin layers, and a set of equations is required to describe the drying process in each layer. Two of these equations are necessary to express the drying rate as a function of the time, and also the drying time as a function of the moisture content. Normally, an empirical model is used with this finality (Aregba et al., 2006; Dantas et al., 2011). In this context, the importance of 
empirical equations in drying simulations is emphasized.

The main objective of this article was to describe the thin-layer drying kinetics of seedless grapes, using empirical models. Hence, several models were selected and the selection obeyed the following criterion: for each selected model, mathematical expressions were obtained to calculate the drying rate and also the process time.

\section{Material and methods}

\subsection{Experimental Data of Seedless Grape Drying}

Experimental data obtained by Esmaiili et al. (2007) for the drying of seedless sultana grapes (Vitis vinifera L.) with hot air are explored in the present paper. In order to increase the skin's permeability to moisture, a pretreatment was applied. The grapes were dipped for $15 \mathrm{~s}$ in hot water at $95{ }^{\circ} \mathrm{C}$. The temperature of the drying air was $50{ }^{\circ} \mathrm{C}$, its relative humidity was $10 \%$, and its velocity was kept at $1.5 \mathrm{~m} \mathrm{~s}^{-1}$. The initial moisture content, $X_{i}$, was $3.25(\mathrm{db})$, and the equilibrium moisture content, $X_{e q}$, was $0.17(\mathrm{db})$.

The dimensionless moisture content data, $X^{*}$, were digitized by using xyExtract Digitizer (http://zeus.df.ufcg.edu.br/labfit/index_xyExtract.htm) and they are presented through Fig. 1.

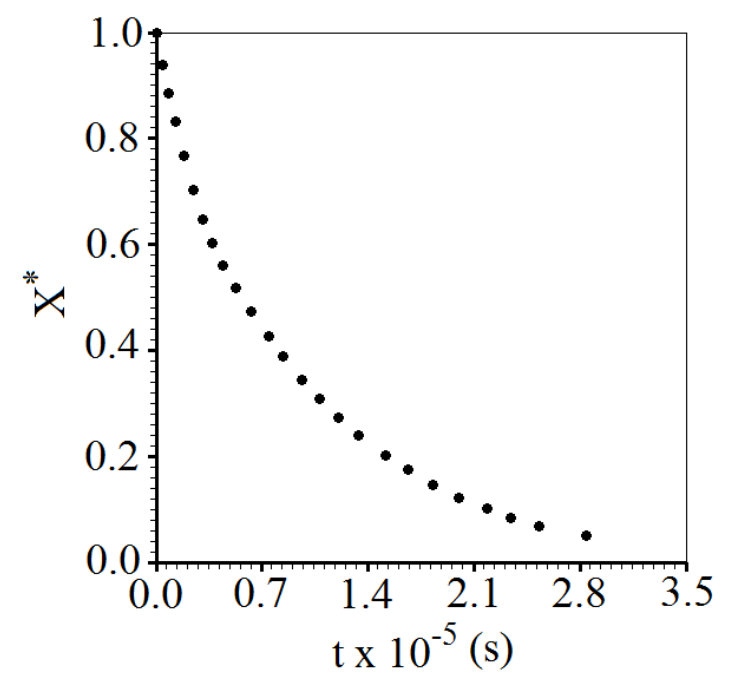

Figure 1. Experimental dataset of seedless grape drying.

\subsection{Mathematical Models}

According to Silva et al. (2013), in many occasions empirical models are seen as a method that only serves to describe the thin-layer drying kinetics of an agricultural product. However, the authors also observed that there are several methods to describe deep bed drying, and one is by dividing the domain into many thin layers. In this case, an empirical equation, together with several other equations, is used to describe the process in each layer. In this case, expressions involving the drying rate as a function of the time, and the drying time as a function of the moisture content are required, and an empirical equation can be used with this finality (Aregba et al., 2006; Dantas et al., 2011). In addition, to describe the heat penetration in a body during the water removal using hot air, an expression involving the drying rate is required (Karim and 


\section{Macrothink}

Journal of Agricultural Studies

ISSN 2166-0379

2014, Vol. 2, No. 2

Hawlader, 2005; Mariani et al., 2008), and normally an empirical model is used to determine this rate. In this context, in order to describe the drying kinetics of seedless grapes using empirical equations, the following assumptions were established:

1) The number of parameters of each model should be only one or two;

2) A mathematical expression for the drying rate as a function of the time should be obtained from each model;

3) A mathematical expression for the drying time as a function of the moisture content must be obtained from each model.

From the first assumption, the moisture content $X$ at time $t$ should be given by an expression of the type:

$$
X=X_{e q}+\left(X_{i}-X_{e q}\right) f(t, a, b)
$$

in which $f(t, a, b)$ is a function with one or two parameters ( $a$ and/or $b$ ), and this function must satisfy all the established assumptions. On the other hand, Eq. (1) can be modified to express dimensionless moisture content at time $t$, as follows:

$$
X^{*}=f(t, a, b)
$$

where

$$
X^{*}=\frac{X-X_{e q}}{X_{i}-X_{e q}}
$$

The selected models are given in Table 1.

Table 1. Empirical models to describe drying kinetics.

\begin{tabular}{|c|l|l|l|}
\hline Model & \multicolumn{1}{|c|}{ Name } & Empirical expression & \multicolumn{1}{c|}{ Reference } \\
\hline 1 & Lewis & $X^{*}=e^{-a t}$ & Kaleta and Gornicki (2010) \\
\hline 2 & Henderson and Pabis & $X^{*}=a e^{-b t}$ & Diamante et al. (2010) \\
\hline 3 & Wang and Singh & $X^{*}=1+a t+b t^{2}$ & Kaleta and Gornicki (2010) \\
\hline 4 & Peleg & $X^{*}=1-t /(a+b t)$ & Mercali et al. (2010) \\
\hline 5 & Page & $X^{*}=e^{-a t^{b}}$ & Diamante et al. (2010) \\
\hline 6 & Silva et alii & $X^{*}=e^{-a t-b \sqrt{t}}$ & Silva et al. (2012b) \\
\hline
\end{tabular}

From Table 1, the mathematical expressions for the drying rate as a function of the time are expressed as is shown in Table 2.

Table 2. Drying rate and drying time expressions obtained through the empirical models. 


\begin{tabular}{|c|l|l|}
\hline Model & \multicolumn{1}{|c|}{ Drying rate } & \multicolumn{1}{c|}{ Drying time } \\
\hline 1 & $d X^{*} / d t=-a e^{-a t}$ & $t=-\ln X^{*} / a$ \\
\hline 2 & $d X^{*} / d t=-a b e^{-b t}$ & $t=-\ln \left(X^{*} / a\right) / b$ \\
\hline 3 & $d X^{*} / d t=a+2 b t$ & $t=\left(-a \pm \sqrt{a^{2}-4 b\left(1-X^{*}\right)}\right) /(2 b)$ \\
\hline 4 & $d X^{*} / d t=-a /(a+b t)^{2}$ & $t=a\left(1-X^{*}\right) /\left(1-b+b X^{*}\right)$ \\
\hline 5 & $d X^{*} / d t=-a b t^{b-1} e^{-a t^{b}}$ & $t=\left(-\ln X^{*} / a\right)^{1 / b}$ \\
\hline 6 & $d X^{*} / d t=-\left(a+b t^{-1 / 2} / 2\right) e^{-a t-b \sqrt{t}}$ & $t=\left[\left(-b \pm \sqrt{b^{2}-4 a \ln X^{*}}\right) /(2 a)\right.$ \\
\hline
\end{tabular}

This table also shows the expressions to determine the drying time for given dimensionless moisture content. Models were fitted to the experimental dataset, using nonlinear regression through LAB Fit Curve Fitting Software (Da Silva et al., 2004), and the results were evaluated through the statistical indicators chi-square and determination coefficient (Taylor, 1997).

\section{Results and Discussion}

It is worth mention that similar studies with other fruits have been investigated and published in the literature using empirical models (Ganesapillai et al., 2008; Diamante et al., 2010; Kaleta and Gornicki, 2010; Kumar et al., 2010; Mercali et al., 2010; Tunde-Akintunde and Ogunlakin, 2011). However, the main focus of these studies is only to describe the thin-layer drying kinetics. In the present article, attention is given to the determination of the drying rate, enabling the use of the obtained results to study the heat penetration and/or deep bed drying.

The obtained results for selected models are presented in Table 3.

Table 3. Results for the drying kinetics described by empirical models.

\begin{tabular}{|c|l|l|l|c|}
\hline Model & \multicolumn{1}{|c|}{$\mathrm{a}$} & \multicolumn{1}{c|}{$\mathrm{b}$} & \multicolumn{1}{c|}{$\chi^{2}$} & $\mathrm{R}^{2}$ \\
\hline 1 & $1.157 \times 10^{-5}$ & \multicolumn{1}{c|}{-} & $1.8898 \times 10^{-2}$ & 0.99651 \\
\hline 2 & 0.95315 & $1.0821 \times 10^{-5}$ & $9.7518 \times 10^{-3}$ & 0.99564 \\
\hline 3 & $-8.7232 \times 10^{-6}$ & $2.0262 \times 10^{-11}$ & $9.4024 \times 10^{-2}$ & 0.97713 \\
\hline 4 & $6.6096 \times 10^{4}$ & 0.81605 & $1.2335 \times 10^{-3}$ & 0.99944 \\
\hline 5 & $5.4682 \times 10^{-5}$ & 0.86327 & $1.9501 \times 10^{-3}$ & 0.99910 \\
\hline 6 & $8.7465 \times 10^{-6}$ & $7.8429 \times 10^{-4}$ & $2.5226 \times 10^{-3}$ & 0.99884 \\
\hline
\end{tabular}

An inspection of the statistical indicators provided by Table 3 makes it possible to conclude that worse model is 3 (Wang and Singh). Models 1 (Lewis), 2 (Henderson and Pabis) and 6 (Silva et alli) are reasonable, but best ones were model 4 (Peleg), with a determination coefficient of 0.99944 and chi square of $1.2335 \times 10^{-3}$; and model 5 (Page), with a determination coefficient of 0.99910 and chi square of $1.9501 \times 10^{-3}$.

The simulation of the drying kinetics using model 4 and the parameters given in Table 3 can be observed in Fig. 2. 


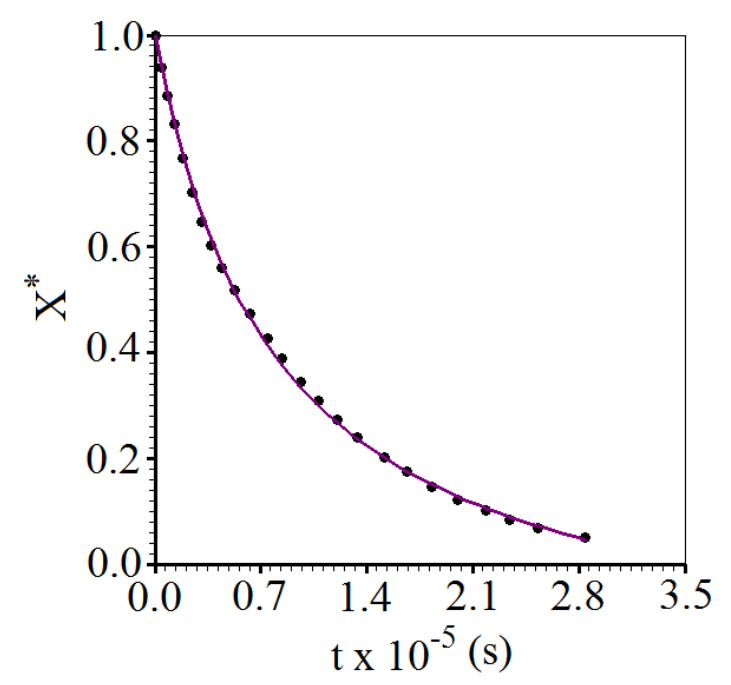

Figure 2. Description of the drying kinetics through model 4 (Peleg).

To observe the coherence between models 4 and 5 during the whole process, Fig. 3 shows the drying kinetics simulations using models 4 and 5, and it is possible to observe in this figure the compatibility between two models, with a little disagreement just at the final part of drying. Even so, Fig. 3 shows that it is difficult to distinguish between the curves generated from models 4 and 5, which means that the models can be considered equivalent.

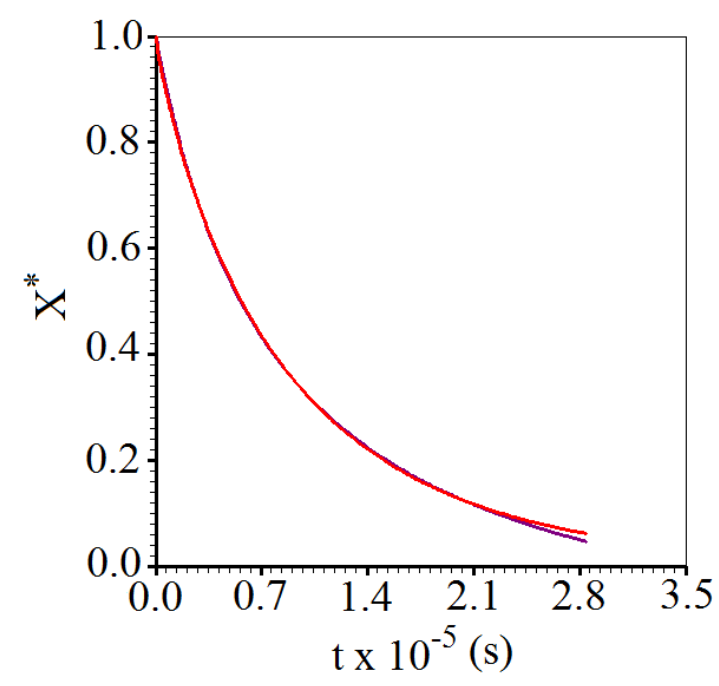

Figure 3. Drying kinetics simulations using models 4 (Peleg) and 5 (Page).

The drying rate referring to model 4 as a function of the time is shown in Fig. 4. 


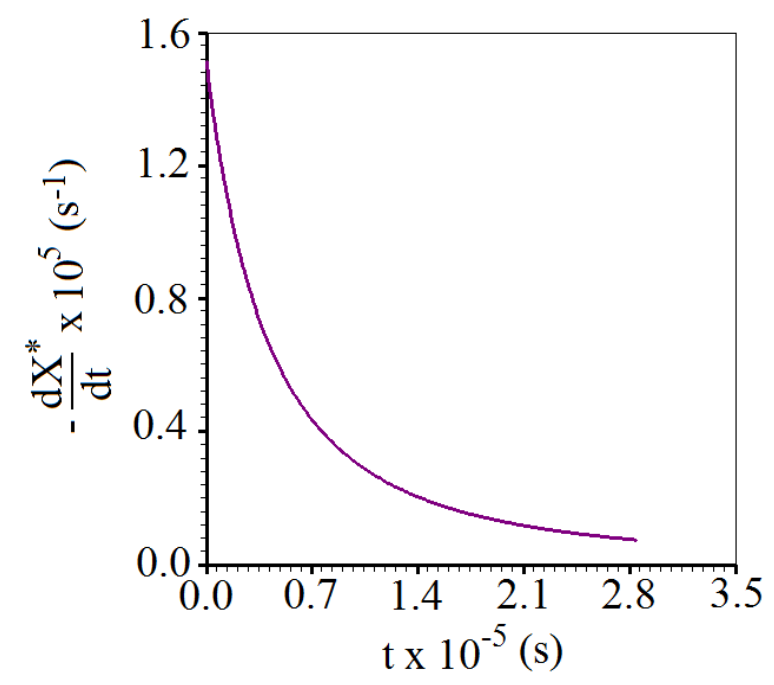

Figure 4. Drying rate calculated using the expression obtained through the model 4.

This figure shows that the drying rate decreases during the whole process, and this behavior also occurs with several other agricultural products (Roberts et al., 2008; Diamante et al., 2010; Kaleta and Gornicki, 2010; Kumar et al., 2010; Mercali et al., 2010; Silva et al., 2012b).

\section{Conclusion}

The experimental dataset makes it possible to conclude that thin-layer drying of seedless grapes took place exclusively in the falling rate period. Among empirical models investigated in this study, the worst result was obtained with Wang and Singh. On the other hand, Lewis, Henderson and Pabis and also Silva et alli are reasonably models to describe the process. According to the statistical indicators, Peleg and Page models well describe the thin-layer drying kinetics of seedless grapes at low temperature. In addition, these two models enable to write mathematical expressions for the drying rate and the process time, and these expressions produce results that can be considered equivalent.

\section{Acknowledgment}

The first author thanks CNPq (Conselho Nacional de Desenvolvimento Científico e Tecnológico) for the support given to this research and for his research grant, Process Number 301697/2012-4.

\section{References}

Aregba AW, Sebastian P, \& Nadeau JP. (2006). Stationary deep-bed drying: A comparative study between a logarithmic model and a non-equilibrium model. Journal of Food Engineering. 77(1), 27-40. http://dx.doi.org/10.1016/j.jfoodeng.2005.06.020

Dantas LA, Mata MERMC, \& Duarte MEM. (2011). Dynamic software for simulation drying of seeds and grains corn (In Portuguese). Revista Brasileira de Produtos Agroindustriais, 13(3), 309-318. http://www.deag.ufcg.edu.br/rbpa/rev133/Art13311.pdf

Da Silva WP, Silva CMDPS, Cavalcanti CGB, Silva DDPS, Soares IB, Oliveira JAS, Silva 
CDPS. (2004). LAB Fit Curve Fitting: A software in Portuguese for treatment of experimental data. Revista Brasileira de Ensino de Física, 26(4), 419-427.

http://www.sbfisica.org.br/rbef/pdf/031102.pdf

Da Silva WP, Silva CMDPS, Farias VSO, Gomes JP. (2012a). Diffusion models to describe the drying process of peeled bananas: optimization and simulation. Drying Technology 30(2), 164-174. http://dx.doi.org/10.1080/07373937.2011.628554

Da Silva CMDPS, Silva WP, Farias VSO, Gomes JP. (2012b). Effective diffusivity and convective mass transfer coefficient during the drying of bananas. Engenharia Agrícola 32(2), 342-353. http://dx.doi.org/10.1590/S0100-69162012000200014

Da Silva, W. P., Farias, V. S. O., Neves, G. A., \& Lima, A. G. B.. (2012c). Modeling of water transport in roof tiles by removal of moisture at isothermal conditions. Heat and Mass Transfer 48(5), 809-821. http://dx.doi.org/10.1007/s00231-011-0931-4

Diamante LM, Ihns R, Savage GP, \& Vanhanen L. (2010). A new mathematical model for thin layer drying of fruits. International Journal of Food Science and Technology, 45(9), 1956-1962. http://dx.doi.org/10.1111/j.1365-2621.2010.02345.x

Di Matteo M, Cinquanta L, Galiero G, \& Crescitelli S. (2000). Effect of a novel physical pretreatment process on the drying kinetics of seedless grapes. Journal of Food Engineering, 46(2), 83-89. http://dx.doi.org/10.1016/S0260-8774(00)00071-6

Doymaz I, Pala M. (2002). The effects of dipping pretreatments on air-drying rates of the seedless grapes. Journal of Food Engineering, 52(4), 413-417.

Doymaz I. (2006). Drying kinetics of black grapes treated with different solutions. Journal of Food Engineering, 76(2), 212-217. http://dx.doi.org/10.1016/S0260-8774(01)00133-9

Esmaiili M, Rezazadeh G, Sotudeh-Gharebagh R, \& Tahmasebi A. (2007). Modeling of the Seedless Grape Drying Process using the Generalized Differential Quadrature Method. $\begin{array}{llll}\text { Chemical Engineering } \quad \text { and } & \text { Technology. } & \text { 168-175. }\end{array}$ http://dx.doi.org/10.1002/ceat.200600151

Ganesapillai M, Regupathi I, \& Murugesan T. (2008). An empirical model for the estimation of moisture ratio during microwave drying of plaster of Paris. Drying Technology 26(7), 963-978.

Kaleta A, Górnicki K. (2010). Evaluation of drying models of apple (var. McIntosh) dried in a convective dryer. International Journal of Food Science and Technology, 45(5), 891-898. http://dx.doi.org/10.1111/j.1365-2621.2010.02230.x

Karim MA, Hawlader MNA. (2005). Drying characteristics of banana: Theoretical modelling and experimental validation. Journal of Food Engineering, 70(1), 35-45. http://dx.doi.org/10.1016/j.jfoodeng.2004.09.010

Kumar R, Jain S, Garg MK. (2010). Drying behaviour of rapeseed under thin layer conditions. Journal of Food Science and Technology, 47(3), 335-338. http://dx.doi.org/10.1007/s13197-010-0054-9 
Mabellini A, Ohaco E, Márquez C, Lozano JE, \& De Michelis A. (2013). Calculation of the effective diffusion coefficients in drying of chemical and mechanical pretreated rosehip fruits (Rosa eglanteria L.) with selected mass transfer models. International Journal of Food Engineering, 9(4), 481-486. http://dx.doi.org/10.1515/ijfe-2012-0001

Malekjani N, Jafari SM, Rahmati MH, Zadeh EE, \& Mirzaee H. (2013). Evaluation of thin-layer drying models and artificial neural networks for describing drying kinetics of canola seed in a heat pump assisted fluidized bed dryer. International Journal of Food Engineering 9(4), 375-384. http://dx.doi.org/10.1515/ijfe-2012-0136

Mariani VC, Lima AGB, Coelho LS. (2008). Apparent thermal diffusivity estimation of the banana during drying using inverse method. Journal of Food Engineering 85(4), 569-579. http://dx.doi.org/10.1016/j.jfoodeng.2007.08.018

Mercali GD, Tessaro IC, Norena CPZ, \& Marczak LDF. (2010). Mass transfer kinetics during osmotic dehydration of bananas (Musa sapientum, shum.). International Journal of Food $\begin{array}{llll}\text { Science } \quad \text { and } & \text { Technology, 2281-2289. }\end{array}$ http://dx.doi.org/10.1111/j.1365-2621.2010.02418.x

Pangavhane DR, Sawhney RL, \& Sarsavadia PN. (1999). Effect of various dipping pretreatment on drying kinetics of Thompson seedless grapes. Journal of Food Engineering 39(2), 211-216. http://dx.doi.org/10.1016/S0260-8774(98)00168-X

Ramos I.N, Miranda JMR, Brandão TRS, Silva CLM. (2010). Estimation of water diffusivity parameters on grape dynamic drying. Journal of Food Engineering 97(4), 519-525.

Roberts JS, Kidd DR, Padilla-Zakour O. (2008). Drying kinetics of grape seeds. Journal of Food Engineering 89(4), 460-465. http://dx.doi.org/10.1016/j.jfoodeng.2008.05.030

Sahoo, N. R., Pal, U. S., Dasha, S. K., Khan, MD. K.. (2012) Drying kinetics and quality aspects during heat pump drying of onion (Allium cepa L.). International Journal of Food Studies, 1, 159-167. http://dx.doi.org/10.7455/ijfs/1.2.2012.a6

Silva WP, Silva CMDPS, Precker JW, Gomes JP, Nascimento PL, Silva LD. (2012a). Diffusion models for the description of seedless grape drying using analytical and numerical solutions. Agricultural Sciences, 3(4), 545-556. http://dx.doi.org/10.4236/as.2012.34065

Silva WP, Silva CMDPS, Sousa JAR, \& Farias VSO. (2012b). Empirical and diffusion models to describe water transport into chickpea (Cicer arietinum L.). International Journal of Food Science and Technology, 48(2), 267-273. http://dx.doi.org/10.1111/j.1365-2621.2012.03183.x

Silva WP, Silva CMDPS, Gama FJA, Gomes JP. (2013). Mathematical models to describe thin-layer drying and to determine drying rate of whole bananas. Journal of the Saudi Society of Agricultural Sciences, 13(1), 67-74. http://dx.doi.org/10.1016/j.jssas.2013.01.003

Taylor JR. (1997). An Introduction to Error Analysis. Second ed. University Science Books, Sausalito, California.

Tunde-Akintunde TY, Ogunlakin GO. (2011). Mathematical modeling of drying of pretreated 


\section{Macrothink}

Journal of Agricultural Studies

ISSN 2166-0379 2014, Vol. 2, No. 2

and untreated pumpkin. Journal of Food Science and Technology, 50(4), 705-713. http://dx.doi.org/10.1007/s13197-011-0392-2

Turhan M, Sayar S, Gunasekaran S. (2002). Application of Peleg model to study water absorption in chickpea during soaking. Journal of Food Engineering, 53(2), 153-159. http://dx.doi.org/10.1016/S0260-8774(01)00152-2

\section{Copyright Disclaimer}

Copyright reserved by the author(s).

This article is an open-access article distributed under the terms and conditions of the Creative Commons Attribution license (http://creativecommons.org/licenses/by/3.0/). 